THE

J O U R N A L

of тин

ROYAL ASIATIC SOCIETY

or

GREAT BRITAIN \& IRELAND.

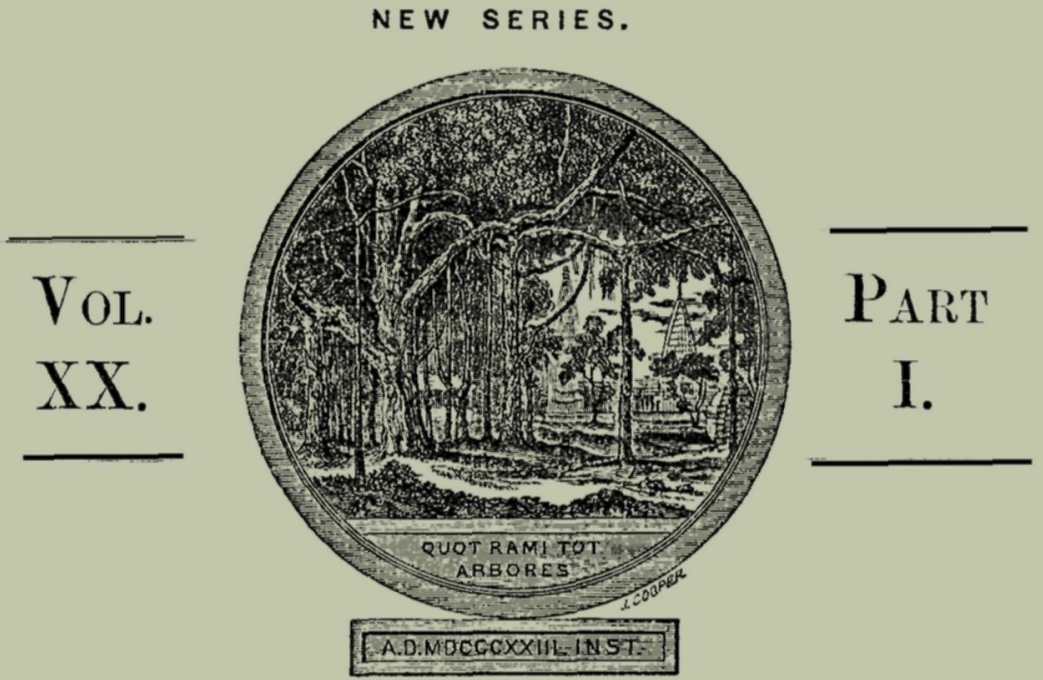

JANUARY, 1888.

L O N D O N :

TRÜBNER \& CO., LUDGATE HILL, E.C.

Price Ten Shillings. 


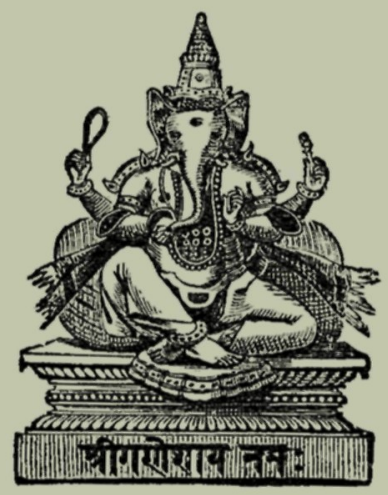

विद्या नाम नरस रूपमधिकं प्रच्छक्नगुप्तं ध विद्या भोगकरी यश्मुखकरी विद्या गुरुखां गुछः । विद्या बन्धुजनो विदेश गमने विद्या परं देवतं विद्या राजसु पूजिता न हि धनं विद्याविहीनः पग़ः :

\section{Messrs. TRÜBNER \& Co.,}

\section{AND 59, LUDGATE HILL, LONDON,}

Respectfully solicit orders for all classes of Publications connected with the History, Antiquities, Geography, and Languages of the East, published abroad. Messrs. Trüвser \& Co. have established agencies in all parts of the East, of Europe, America, and the Colonies, and are thus enabled to furnish such publications with as little delay as possible.

Authors desirous of having works printed can be furnished with Specimens, and Estimates for Paper, Printing, and Binding, and every tacility will be afforded them of bringing the same advantageously before the public. 


\section{TR ÜB NER \& C O.'S}

\section{MONTHLY LIST.}

Vol. XII., No. 1.

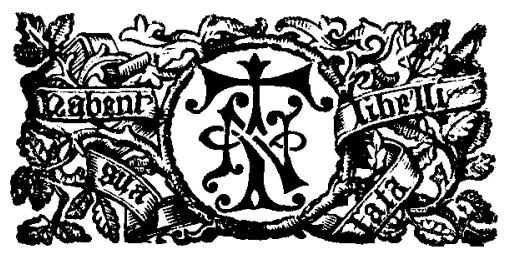

Jan., 1888.

Messrs. TRÜBNER d CO. have constantly on hand a large Col. lection of Works in all Branches of Literature published in Europe, North and South America, Africa, and the East ; and being in direct. and regular communication with the leading Publisher's, are able to supply all such Works at a reasonable price. .

Books not in Stock supplied with the utmost despatch.

Messrs. TRÜBNER d CO. have always a large and select stock: of Vocabularies, Reading Books, Grammars and Dictionaries in all Languages. Catalogues on application.

\section{NOW READY.}

Volumes I. and II., demy 8 vo, cloth, price $£ 2$ I2s. $6 d$. for the Complete Work.

\section{SOUTH.AFRICAN BUTTERFLIES:}

A Monograph of the EXTRA-Tropical Species.

BY

ROLAND TRIMEN, F.R.S., F.L.S., F.Z.S., F.Ent.S., \&c. Curator of the South-African Museum, Cape Town;

\section{ASSISTED BX}

JAMES HENRY BOWKER, F.Z.S., F.R.G.S.

Colonel (Retired) in the Cape Service;

Late Commandant of the Frontier Armed and Mounted Police ;

Ciovernor's Agent in Basutoland, and Chief Commissioner at the Diamond Fields of Griqualand West.

Vol. I. NYMPHALID 2 . Pp. xiv, and 335 .

Vol. II. ERYCINIDA世 AND LYCANIDAm. Pp. 242. $\}$ Now ready.

With a Map and Nine Coloured Plates.

Vol. III., completing the work, is in a forward state, and will be issued to subscribers at an early date.

London: TRÜBNER \& CO., Ludgate Hill. 
NOW READY.

Crown 8vo, cloth, pp. vi. and 263 , price $7 s .6 d$.

\section{O T U S A N D JEWEL. \\ CONTAINING}

"IN AN INDIAN TEMPLF," "A CASKET OF GEMS,"

"A QUEEN'S REVENGE."

WITH OTHER POEMS.

$B Y$

EDWIN ARNOLD, C.S.I.

Author of "The Light of Asia," \&c. \&c.

MURRAY's MAGAZINE.-_" The first of these poems, 'In an Indian Temple,' opens with a lovely description of the temple. An Englishman and a Pundit discuss the Indian and the Christian ideal of the highest good, while a Nautch girl, 'mocking all save love,' sings snatches of melodious and passionate songs. The whole scene in the 'warm blue Indian air' is charmingly conjured up, and the exposition of the Brahmin creed is fine. In contrast to this, the series of poems on precious stones which follows seems laboured and heavy. Mr. Arnold's power of conveying glowing, varied and sensuous impressions of a strangely different state of existence is better exemplified by two translations from the Sanskrit and some of the short poems on Indian Subjects."

PALL MALL GAZETTE,-“This volume. . . fully maintains Mr. Arnold's repulation. It contains three principal poems, of which the first in order, 'In an Indian Temple,' seems to us the best. The second, 'A Casket of Gems,' is full of delicate and graceful fancy, its diction is rich even to gorgeousness, while passages showing depth of feeling occur again and again. The third, 'A Queen's Revenge,' is a translation from the Sanskrit of the Mahabharata. Powerful certainly it is, and it casts, as Mr. Arnold remarks, a curious light on "ancient Indian life and manners."

WhItehall ReVieW._" Mr. Edwin Arnold is a poet, a scholar and a student; he knows what he is writing about, and he writes beautifully. . . . He has brought many precious Eastern things to our market, and so we are very grateful to him."

ACADEMY._-"The book is full of charm."

SCOTSMAN._-"Style and rhythm are, as in all Mr. Arnold's poems, rich and melodious, the imagery is beautiful and appropriate, and the thoughts warm and noble."

Crown 8vo, cloth, pp. $1 \$ 6$, price $6 s$.

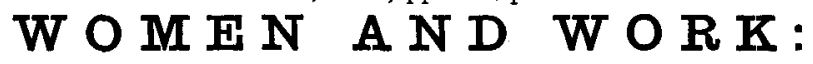

An Essay on the Relation to Health and Physical Development of the Higher

Education of Girls, and the Intellectual or more Systematical

Efort of Women.

BY

\section{EMILY PFEIFFER,}

Author of "Gerard's Monument," "Under the Aspens," "The Rhyme of the Lady of the Rock," "Flying Leaves from East to West,"

"Sonnets," \&c. \&c. \&c.

PALL MALL GAZETTE._- "Among all the books and treatises which have recently been written on the subject of women's work, there is not one which equals the present in interest and hopefulness. Mrs. Pfeiffer considers all the timid reasons of the opponents of the "women movement,' and by hard, authenticated facts confutes their doubts."

LITERARY WORLD.- " Although a poetess of some eminence, Mrs. Pfeiffer cannot be accused of lack of practical common sense by any reader of this work. ' In a careful preliminary chapter the sentimental difficulty raised by objectors to the higher education of women is considered, and fairly met with reasonable argument. The economic and physiological problems are examined, medical testimony and statistical evidence are given, both for and against such education; and in a closing chapter the whole matter is summed up with the concession that some loss of tender dependence may result, but only to lead to sweet and nobler developments in womanly character when set íree from the bondage of ignorance and helplessness. A volume well worth reading." 
NOW READY.

Crown 8vo, cloth, pp. 62, price Is. 6 d.

\section{DEATH-AND AFTERWARDS.}

Reprinted from the "Fortnightly Reviecu" of August, i 885, with a Supplement.

BY

\section{EDWIN ARNOLD, M.A., C.S.I.}

Author of "The Light of Asia," \&c.

MANCHESTER GUARDIAN._-"A notable essay on the problem of immortality. . . . Mr. Arnold's booklet is likely to attract attention."

Bristol MERCURY.-.. "There are, undoubtedly, many original and quaint ideas set forth in the book."

ABERdeEn DAILY FREe Press._-_"This subtle and suggestive essay on the immortality of the soul, by one of the most cultured of living poets . . . is inspired by a pure and emphatic faith, based on thorough scholarship and poetic insight."

BRITISH WEEKLY._" "Mr. Edwin Arnold has been wisely advised in reprinting from the Fortnightly Review his article, 'Death-and Afterwards.' It effectually breaks windows through the prison walls which materialism and unbelief build around us, and suffers us to breathe an ampler air. Nothing could surpass these few pages in felicity of statement or in persuasiveness."

\section{EGYPT EXPLORATION FUND.-FOURTH MEMOIR.}

Royal 4 to, boards, pp. iii. and 26, with Eleven Plates, price $£$ I $5 s$.

\section{THE SHRINE OF SAFT EL HENNEH AND THE \\ LAND OF GOSHEN.}

(1 88 B.)

BY

EDOUARD NAVILLE.

Royal 8 vo, cloth, pp. ix, and 283 , price I0s. $6 \%$.

\section{THE BHAGAVAD GÎTÂ;}

OR, THE LORD's LAY.

With Commentary and Notes, as well as references to the Christian Scriptures.

Translated from the Sanskrit for the benefit of those in search of Spiritual Light.

MOHINI M. CHATTERJI, M.A.

The Bhagavad Gîtâ is well known to Students and Scholars. In this transiation an attempt is made to present the Bhagavad Gitat as a Scripture to those in search of Scriptural Light. The text, comment and notes of the Sankarâcharya version are followed, and adapted, as far as possible, to Western modes of thought. 


\section{THE ENGLISH AND FOREIGN PHILOSOPHICAL LIBRARY.}

\section{NOW READY.}

SLCoNo Edition. Post 8vo, cloth, pp. $\mathrm{xx}$, and 320 , price 7 s. $6 a$.

\section{THE PHILOSOPHY OF MUSIC.}

\section{A Polular exposition of the General Theory of the Art AS BASED ON THE RESEARCHES OF HELMHOLTZ.}

Being the Substance of a Course of Lectures delivered at the Royal Institution of Great Britain, in February and March, 1877.

BY

WILLIAM. POLE, Mus. Doc. Oxon.

Fellow of the Royal Societies of London and Edinburgh; one of the Examiners in Music to the University of London.

In this edition some amendments and additions have been introduced, and some changes haze been made in the mode of speaking of the asthetics of the art. This subject, or at least the most important part of it, is now becoming, under the name of Musical Psychology, a special science so elaborate and difficult that it would be out of place to undertake, in a general technical work of this kind, any discussions connected with it. In the matter of asthetics, therefore, the scope of this treatise goes no farther than is necessary $t$ s explain the nature and origin of the ordinary forms and rules of musical structure.

\section{NOTICES OF THE FIRST EDITION.}

ACADEMY.- "The work of Dr. Pole is that of an accomplished musician."

Scotsman. - "They constitute, it may be asserted with confidence, one of the most important contributions yet made to the literature of musical science in the English language. - . What he has sought to do is to present such an exposition of the results of the profound investigations of Helmholtz as shall be intelligible both to practical musicians and to such of the general public as take an intelligent interest in musical art. In order to accomplish this, however, much was necessary in the way of preliminary explanation; and furthermore, the intricacy and abstruseness of portions of the subject are so great as to make the task of popular elucidation exceedingly arduous. Mr. Pole has, however, successfully accomplished it . . . It is an admirable introduction, and will make its own way to recognition among the class of readers to whom it most directly appeals."

PALL MALL GAZETTE._-We may recommend it as an extremely useful compendium of modern research into the scientific basis of music. There is no want of completeness."

TrUTH- "Dr. Pole's 'Philosophy of Music' is likely to find fit audience, and through these to exercise a beneficial influence on the study of the fundamental principles of musical composition, both ancient and modern."

MUSICAL TIMES._- "Will be read with eagerness by a large class of readers." 


\title{
NOW READY.
}

Fcap. folio, half vellum, pp. xii. and 118 , price 8 s. $6 d$.

\section{O T U S L E A V E $\mathbf{S}$.}

$\mathrm{BY}$

\section{ST. CLAIR BADDELEY.}

Scotsman. - "His poems are chiefly tales in blank verse, based on Hindu legend and mythology. . . . They display a clear warmth of imagination. . . Mr. Baddeley's verse is melodious and dignified."

Royal I6mo, cloth, pp. vii. and 304 , price $3 s .6 d$.

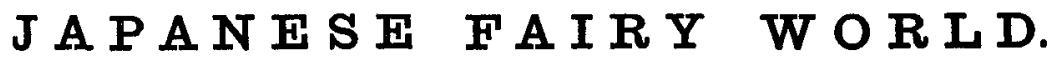

STORIES FROM THE WONDER-LORE OF $\mathcal{F} A P A N$.

BY

WILLIAM ELLIOT GRIFFIS,

Author of "The Mikado's Empire."

lllustrated by OZAWA, of Tokyo.

\section{ROWBOTHAM'S SERIES OF POETICAL ROMANCES.}

\author{
No. I.
}

$4^{\text {to, }}$ cloth, pp. vi. and 176 , price 10 .

\section{THE DEATH OF ROLAND: \\ AN EPIC Poem.}

\section{BY \\ JOHN FREDERICK ROWBOTHAM,}

Author of "The History of Music."

The Death of Roland will be the first Volume of a Series of "Poetical Romances" in which the author introduces a newe Form into Literature. The Poetical Romance is a novel in Verse and may be looked upon as the popularising of the Epic Poem, which is here lightened of much of its stiffiess, clipt of its inordinate length, and reduced to proportion and style within the sympathies of modern readers.

SUNDAY TIMES.—"This poem is a delightful epic marked by strong poetic feelings, and the perception on the part of the Author of all that is true, glorious, and ennobling in life and in death of a high-minded chivalrous soldier; for so is Roland 'the peerless Paladin.' . . . . It affords us the heartiest satisfaction to call attention to this delightfully-told story, which is the joint production of genius, scholarship and industry, which so happily combines in placing Mr. Rowbotham among the first of English writers."

CoventRY TIMES.- "In vivid verse Mr. Rowbotham depicts the deeds of daring performed by the brave warrior who accompanied Charlemagne to the conquest of Spain."

WARWICKSHIRE TIMES.- "The celebrated and chivalric Roland, who is the hero of the poem, was one of the paladins of Charlemagne, and his adventurous career has been the theme of some of the most famous of Continental romances, but nowhere have his heroic deeds been depicted in more thrilling terms than in this powerful poem." 
NOW READY.

\title{
Crown 8vo, cloth, pp. viil. and 4I4, price I2s. \\ T H $\mathbf{E} \quad \mathbf{S}$ I $\underset{\text { OF }}{\mathbf{N}} \mathbf{C}$ L A I R S \\ E N G L A N D.
}

SCOTSMAN.-“ Full of recondite learning, and written withal in a free and popular style of narrative not often exemplified in such works. . . . That the work is a valuable one no one who reads it will be disposed to deny. . . To antiquarians and genealogists it will, presumably, give unmixed pleasure. . . . The book has so much purely historical matter in it that a lover of simple history will be glad to possess it. It is plainly the result of much laborious research, and its unconventional style makes it more easy and pleasant to read than most works of a like kind."

JOHN O'GROAT JOURNAL,_-" "The Sinclairs of England' is a closely-printed volume of 4 I4 pages, embracing an exhaustive sketch of many of the most illustrious men of that name. It is a work no Scottish library should be without, on account of the valuable side-light it throws on the events of current history. The quotations from old deeds, the authorities quoted from some of the oldest library collections are ever valuable in tracing the record of exalted personages. . . . The work is one of rare antiquarian merit."

Crown 8vo, cloth, pp. viii. and 214, with Eight Plates, price $7 s .6 d$.

\section{THE ICELANDIC DISCOVERERS OF AMERICA ;}

OR, HONOUR TO WHOM HONOUR IS DUE.

BY

MARIE A. BROWN,

Author of "The Sunny North ; or, Sweden of the Past and of the Present," "Norway as it Is," and Translator of "The Surgeon Stories," "Nadischda," the "Schwartz" Novels, \&c.

ILLUSTRATED LONDON NEWS.- "A small volume which contains much that is instructive, especially the abundant passages extracted from authors of good repute who have treated of Scandinavian history."

ANTIQUARY.- "The Sagas containing the narrative give very valuable glimpses of early Scandinavian life, many traits of which are admirably brought out by Miss Brown."

AMERICAN REGISTER (Paris).-- "Will be read with much interest, in view of the approaching fourth Centenary of Columbus's discovery of America."

\section{Demy 8vo, pp. viii. and 360 , cloth, price 88.
ORIGIN OF THE GREK, LATIN AND
GOTHIC ROOTS.}

\author{
BY \\ JAMES BYRNE, M.A. \\ Dean of Clonfert ; \\ Ex-Fellow of Trinity College, Dublin ; \\ Author of "General Principles of the Structure of Language."
}

SCOTSMAN._"The elaborate classification of words and roots forms a solid contribution to the literature of comparative philology. . . . The well-compiled series of full indices makes the work easily available for reference, and adds considerably to its value."

BOOKSELLER. - "Mr. Byrne is well known as one of the most learned and accurate philologists of the day, and the work with which he now follows up his 'General Principles of the Structure of Language' will be found no less deeply thought out, and demanding as careful an attention." 
NOW READY.

Demy 8 vo, cloth, pp. vi. and $₫ 20$, price $5 s$.

\section{VER NER'S LAW IN ITALY:}

An Essay in the History of the Indo-European Sibilants. liv

\section{R. SEYMOUR CONWAY,}

Gonville and Caius College, Cambridge; Waddington Classical Scholar in the University of Cambridge; Exhibitioner in Latin in the University of London.

With a Dialect Map of Italy by E. HEAWOOD, B.A., F.R.G.S.

SCOTSMAN._-"A minute examination of the rules which govern the change of $s$ into $r$ in the dialects of Italy. Mr. Conway's book is too recondite to appeal to any but special students of philology. These, however, will read it with interest and instruction. It is a work of good scholarship, based upon wide and accurate knowledge of the most recent investigations in linguistic science, and reasoned out with commendable care."

Part II., demy 4to, boards, pp. 96, price 5 s.

\section{A DICTIONARY}

OF THE

\section{TARGUMIM, THE TALMUD BABLI \& YERUSHALMI AND THE MIDRASHIC LITERATURE.}

Compiled by M. JASTROW, Ph. D.

This Dictionary, of which Parts $I$. and II. are now ready, is intended as a guide to a study beset with difficultics. Scholars and students, though acquainted with Biblical Hebrew and cognate tongues, have been deterred from taking up Talmudic literature by the apparent hopelessness of the task without a guide. It is this want which the proposed work, the first of the kind in English, aims to supply.

Royal 8vo, cloth, pp. I74, price I $2 s .6 d$.

\section{A TREATISE ON SYRIAC GRAMMAR.}

BY

MÂR(I) ELIÂ of SÔBHÂ.

Edited and Translated from the Manuscripts in the Berlin Royal Library

BY

\section{RICHARD J. H. GOTTHEIL.}

Eliâ of Sôbhâ stands, as regard's form and subject matter, much nearer $\mathcal{F}$ akốbh than does Eliâ of Tirhân. His style is clear and concise; the rules are given in $a$ dry-at times monotonous-manner, but, also without ever attempting to force the Syriac into grammatical forms to which it is quite strange. As a representative of the School of Sôbha, and a starting point for a number of later grammarians, he claims the full interest of scholars. 


\section{NOW READY.}

Crown 8 vo, cloth, pp. xii. and 80 , price 3 s. $6 d$.

\section{A L A S S I O : \\ "A PEARL OF THE RIVIERA."}

\section{DR. JOSEPH SCHNEER.}

SATURDAY REVIEW.- "A readable brochure on a new winter resort . . . depicts the attractions of Alassio with convincing force. Both in climate and scenery, the Ligurian watering-place possesses great advantage over the French Riviera."

MORNING POST.- "Dr. Schneer's object in directing attention to Alassio is to enable those who seck for peace and rest to find it in this lovely and tranquil spot. After a brief but interesting history of the place, he gives a pleasant sketch of the people and their manners and customs, followed by a few remarks on trade and industry. The scenery in the neighbourhood of Alassio is both varied and beautiful, and several charming excursions are suggested."

Demy 8vo, cloth, pp. viii. and 204, price $7 s .6 d$.

A SHORT PRACTICAL TREATISE ON THE

\section{NATURE, CAUSES, AND TREATMENT OF CHOLERA.}

As a SUPplenent to the History of Cholera in INDia, From I 862 to 188 r.

BY

Deputy Surgeon-General H. W. BELLEW, C.S.I.

Bengal Army (Retired).

The object of the present work-which is supplementary to the author's larger book, "The History of Cholera in India from 1862 to $188 \mathrm{I}$ " published in 1885 , and contains the detailed tabular statistics of Cholera mortality and Rainfall from which the abstracts in the former work were compiled-is to describe the nature and causes of cholera in plain language, intelligible to all understandings, with $a$ view to the clearer perception of the measures of precaution and medical treatment-preventive and curative-which afford the most reliable means of entirely escaping, or of safely tiding over, an attack of the disease.

Crown 8vo, cloth, pp. I7o, price $2 s .6 a$.

\section{THE TONIC TREATMENT OF EPILEPSY AND} KINDRED NERVOUS AFFECTIONS.

\section{BY WALTER TYRRELL, M.R.C.S.}

To profess a disbelief in an established method of treatment of disease is a bold and somewhat thankless office, more especially when the method attacked is one which has been so universally adopted, and so widely practised, as the Bromide treatment of Epilepsy. . . . A wider experience is proving that the use of Bromides produces merely temporary and palliative results, and that the only plan by which it is possible to effect permanent cure is by restoring to the nervous constitution that poperer of control, the loss of which constitutes the disease. 
NOW READY.

Crown 8vo, cloth, pp. xi. and $24 \mathrm{I}$, price $4 s$. $6 d$.

\section{B O R R O W E D L U M E S.}

TRANSLATIONS FROM GERMAN POETS.

BY

JAMES D. B. GRIBBLE.

Contains selections from Heine, Bodenstedt, Gunther Walling, Geibel, Heyse, GoeTHe, Schill.er and others. With German original and English translation on opposite pages.

Ficap. 8 vo, boards, pp. viii. and 100 , price Is.

\section{PRESQUE MOT A MOT.}

ou

LIVRE DE LECTURE POUR LES COMMENCANTS.

$\mathrm{BY}$

A. SAUVAIN.

Formerly Teacher of Modern Languages in Burnley and Clitheroe Grammar Schools.

\section{OXFORD LOCAL EXAMINATIONS.}

Eighth Edition, I $2 \mathrm{mo}$, cloth, pp. II3, price $3 s .6 \%$.

D E U T $\mathbf{S}$ C H E I I E B E.

AUS DEN PAPIEREN EINES FREMDLINGS.

Herausgegeben und mit einem Vorwort begleitet.

Von F. MAX MÜLLER.

Prescribed by the Board of the Oxjord Local Examinations for 1888.

With Notes for the use of Schools.

Crown 8vo, cloth, pp. cvi. and 339, price 5s. $6 d$.

\section{工 O N D I N I S M E N . SLANG UND CANT.}

Alphabetisch Geordnete Sammlung der Eigenartigen Ausdrucksweisen der Londoner Volkssprache Sowie der Üblichsten.

Gauner-, Matrosen-, Sport- und Zunft-Ausdrucke.

Mit einer Geschichtlichen einleitung und musterstïken. Ein Supplement zu allen Eng.Deutschen Wörterbiichern.

Von HEINRICH BAUMANN, M.A. 


\section{NEARLY READY.

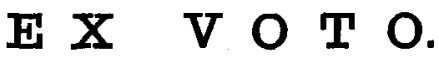

An Account of the Sacro Monte, or New Jerusalem, at Varallo-Sesia.

With Photographs of "II Vecchietto."

BY

SAMUEL BUTLER,

Author of "Luck or Cunning;" "Life and Habit;" "Evolution, Old and New," \&c. \&c.

Seventh Edition, Crown 8vo.

\section{E R E W H O N;}

OR, OVER THE RANGE.

LY

SAMUEL BUTLER.

\section{BULGARIA, PAST AND PRESENT.}

Historical, Political AND Descriptive.

Illustrated with Map by Stanford, numerous Photographs and Woodcuts from Original Sketches by the Author.

BY

JAMES SAMUELSON,

Author of "Roumania, Past and Present," \&c.

Small 4 to.

\section{THE. GOSPEL BY IMTTHEW. IN THE}

\section{ABORIGINAL LANGUAGE OF FORMOSA,}

With Corresponding Versions in

\section{DUTCH AND ENGLISH.}

Reprinted, with an Introduction, from the Amsterdam Edition of 1661 .

Rev. W. CAMPBELL, F.R.G.S.

English Presbyterian Mission, Taiwanfoo.

This Reprint has been made through the courteous kindness of the Authorities con. nected with the University Library in Leiden, where the only known copy of the original work is preserved. The object mainly intended in its preparation has been a revizal of the extensive educational and Christianising work carried on by the Dutch in Formosa 250 years ago; but, from Professor de Lacouperie's fresh and exhaustive article in the Fuly number of the Royal Asiatic Society's Fournal, it may be inferred that this specimen of the language, now made thus accessible for the first time, will be welcomed by many scholars who are interested in the Languages and Races of the East. 
NEARI, Y READY.

Crown 8 vo.

THE FORTUNES OF WORDS :

LETTERS TO A LADY.

$\mathrm{BY}$

FEDERICO GARLANDA, Ph.D.

Second Edition. Crown 8vo.

WIT, WISDOM AND PATHOS

From the Prose of

HEINRICH HEINE.

With a few Pieces from the "Book of Songs." Selected and Translated by

J. SNODGRASS.

Vol. I. (I608-I682), demy 8vo.

H I T O R Y OF C A N A D A.

BY

WILLIAM KINGSFORD.

In Three Volumes.

Demy 8vo.

\section{SOCIAL HISTORY OF THE RACES OF M A N K I N D.}

THIRD DIVISION :

O CEANO MELANESIANS.

$\mathrm{mY}$

A. FEATHERMAN.

Post 8vo.

A LANGUAGE-STUDY BASED on BANTU ;

OR, AN INQUiRY INTO THE LAWS OF ROOT-Formation.

The Original Plural, the Sexual Dual and the Principles of Word Comparison.

With Tables Illustrating the Primitive Pronominal System restored in the African Bantu

Family of Speech.

BY

The Rev. F. W. KOLBE,

Of the London Missionary Society, formerly of the Rhenish Herero Mission ;

Author of "The English-Herero Dictionary." 


\section{NEW EDITION OF THE IMPERIAL GAZETTEER OF INDIA.}

Published by Command of the Secretary of State for India.

\section{NOW READY.}

In Fourteen Volumes, demy $8 v 0$, half-morocco, price $£ 33^{s}$.

THE

\section{IMPERIAL GAZETTEER OF INDIA.}

BY

\section{Sir WILLIAM WILSON HUNTER, K.C.S.I., C.I.E., LL.D.}

Member of the Governor-General's Council ;

Late Director-General of Statistics to the Government of India.

TIMES. - "Without a precedent in national, literary or statistical enterprises. . . . It is in truth a minute account, compiled from local survey, of every large village, town, district, province, river, mountain and port throughout a region equal in area and population to all Europe, excluding Russia. . . The information given on subjects connected with the practical questions of the day is clear and abundant. . . . This vast magazine of fact and learning is a marvellous combination of literary condensation and original research. . . . Sir W. Hunter has enjoyed special opportunities and exceptional facilities; they have been amply justified by the exceptional skill and success to which he has turned them."

DAILY TELEgRAPH. - "The harvest of seventeen years of unremitted labour. . . . Of the enormous labour, the talent for organisation, and the sustained literary power required for the execution of such a task, it is difficult to speak too highly. . . However, we must find room for a warm and unqualified meed of praise for the amazing vigour and verve of his vast compilation, for its lucid and large generalisations; its opulence of details, its enormous range of facts and statistics, its high and pervading intelligence, and the masterly scheme and ample execution of the labour. For these both India and England owe Sir W. Hunter a debt of gratitude."

Asiatic QuARTERLy RevieW.- “The original edition of nine volumes of Sir W. W. IIunter's Imperial Gazetteer of India, was, perhaps, the most valuable work ever published relating to India. The new and revised edition, just issued in thirteen volumes by Messrs. 'Tribner under the direction of the Government of India, approaches perfection as nearly as is possible for any human undertaking. It is remarkable for the mass of information contained in its pages, but it is still more remarkable for the skill shown in the arrangement of this informa. tion, and for the lucidity of the descriptions."

THE TIMES OF INDIA.- " In his Gazetteer he has rendered the Indian Government the highest service that a public servant can achieve. His Gazetteer, even in the form of the first edition, was a work of almost unrivalled labour and individual responsibility, reminding us, as we said at the time, of nothing so much as Dr. Johnson's English Dictionary. Sir W. Hunter, as we then said, accomplished for India, 'geographical, political and statistical,' exactly what Dr. Johnson in his great dictionary did for the English tongue; and there was much in the enormity of the labour, the infinite detail, the precision of language, the absence of former material, and the great individual responsibility of the one writer to remind us of the other." 


\section{(1) Excial and othex Authorised Anblications.}

JUST ISSUED.

\section{PUBLICATIONS OF THE ROYAL SOCIETY.}

Separate papers from the Philosophical. Transactions. Vol. i78, i887.

ON FIGURES OF EQUILIBRIUM OF ROTATING MASSES OF FLUID. BY G. H. DARwin, M.A., LL.D., F.R.S. 4to, paper, pp. 5o, with Two Plates, 2s. $6 d$.

(A 13. )

ON THERMAL RADIATION IN ABSOLUTE MEASURE. By J. T. BotTomley, M.A. 4to, paper, pp. 22, with Three Plates, price Is. 6 d.

(A I4.)

ON THE SUPPOSED “ NEW FORCE" OE M. J. THORE. By WILliaM CROOKES, F.R.S., Pres, C.S. 4to, paper, pp. 20, with Illustrations, price Is.

(A 15.$)$

A MINUTE ANALYSIS (EXPERIMENTAL) OF THE VARIOUS MOVEMENTS PRODUCED BY STIMULATING IN THE MONREY DIFFERENT REGIONS OF THE CORTICAL CENTRE FOR THE UPPER LIMB, AS DEFINED BY PROFESSOR FERRIER. By Charles E. BeEvor, M.D., M.R.C.P., and Victor Horsley, B.S., F.R.C.S., F.R.S. 4to, paper, pp. I6, with One Plate, price Is. (B 6.)

THE FMBRYOLOGY OF MONOTREMATA AND MARSUPIAIIA. Part I. By W. H. CALowall, M.A. 4to, paper, pp. 2 , with Three Coloured Plates, price $3 s$.

\section{PUBLICATIONS OF THE PHILOLOGICAL SOCIETY.}

\section{TRANSACTIONS 1885-7. PART II., price I 5 s.}

Fourteenth Address of the President to the Philological Society, delivered at the Anniversary Meeting, Friday, 21st May, I886. By the Rev. Prof, SKEAT, M.A., LL.D.

Introduction.

Obituary-Mr. Bradshaw, Mr. Walter Raleigh Browne, Professor Cassal, Archbishop Trench, Dr. Stock.

Report by the President on the Work of the Philological Society.

The President on "Ghost-Words."

IV. R. MORFIL on Slavoni: Philology (April, I $98_{4}$, to April. I886).

J. BoxwelL on Sontali.

Prof. Thurneysex on Celtic Philology.

Prof. TFRRIEN DE LACOUPERIE on the Languages of China before the Chinese.
The Breton Glosses at Orleans. By Whituey STOKES, D.C.L., \&c.

Remarks on the Oxford Edition of the Battle of Ventry. By S. H. O'GrADY.

On the Derivations of "Cad," "Lither," "Ted." By H. WEDGwOoD, M.A.

The Origin of the Augment. By the Rev, A. H. SAYCE, M.A.

On the Place of Sanskrit in the Development of Aryan Speech in India. By J. Boxwely, H.M. Bengal Civil Service.

The Primitive Home of the Aryans. By the Rev. Prof. Sayce, M.A.

Notes on English Etymology. By the Rev. Prof. SKEAT, LL.D.

Index.-.-Monthly Abstracts for the Sessions $188_{5-1} 6$ and $1886-7 .-$ List of Members (Corrected to October, 1887 ).

\section{PUBLICATIONS OF THE ROYAL SOCIETY OF LITERATURE.}

\section{TRANSACTIONS.-SECOND SERIES. Vol. XIV. Part I., price}

Notes on the History of the Shakespearian Canon. By C. M. INGLEBY, LL.D., V.P.R.S.L.

The Aryan Birthplace. By Charles J. Stone, F.R.S.L.

The Philosophy of Epicurus and Modern Agnosticism. By WILLIAM KNIGHTON, LL.D., V.P.R.S.L.

The Mythology, Legends, and Folk-Lore of the Algonkins, By Charles G. Leland (Hans Breit. mann), Hon. F.R.S.L.
On the Origin, the Manners, Customs, and Institutions, and the Annihilation of the Aborigines of Australasia. By J. Henniker Heaton, F.R.S.L., M.P.

Historical Sketch of St. Thomas's Hospital. Part If. By William Rendle, F.R.C.S.

Grotius and the Literary History of the Law of Nations. By C. H. E. CARMichafL, M.A., Foreigu Secretary, R.S.I.

\section{PUBLICATIONS OF THE BROWNING SOCIETY.}

PAPERS. I886-'7. Part VIII.

On the Development of Browning's Genius in his Capacity as Poet or Maker. By $J$.' $T$. NeTrLeship. On Aristophane's Apology. By J. B. Burv, B.A.

Un the Avowal of Valence (Colombe's Birchday). By L.S. OUtram.

On Andrea del Sarto. By A. Fleming.

On Erowning as a Landscape Painter. By H. S. PEARSON.
(Part II. of Vol. II.) Price Ios.

On the Reasonable Rhythm of Some of Mr. Browning's Poems. By Rev, H. J. BuLKELEV, M.A. On Prince Hoenstiel-Schwangau. By C. H. HER. FORD, M.A.

The Monthly Abstract of Proceedings of Meetings-Browning "Notes and Queries "-Report of Com.
mittee-188, 6 . 
NEW AMERICAN BOOKS.

Crown 8 vo, cloth, price 7 s.

\section{GRAY'S LESSON I N BOTANY.}

REVISED Edition.

\section{THE ELEMENTS OF BOTANY.}

For Beginners and for Schools.

BY ASA GRAY.

Royal 8vo, cloth, Illustrated, price $£ 22 s$.

\section{THE POETICAL WORKS OF SIR WALTER SCOTT.}

Revised, Corrected and Edited, with Notes and Commentaries,

By Wm. J. ROLFE.

Editor of the "Students' Series of Classic Poems," "Students' Shakespeare," \&c.

$M r . W . J$. Rolfe, the accomplished editor of the "Students' Series of Poetry," and of Shakes. peare, has undertaken the herculean task of editing and restoring the correct and original text, and of producing in one volume THE FIKST AND ONLY CORRECT EDITION in England or America of Scott's Poems. All existing editions of Sir Walter Scott's poetry or single poems, except those edited by Mr. Rolfe, are disfigured and rendered untrustworthy throughout by gross and numerous errors and misprints. This edition contains full notes and appendices, with preface and comments by $M r$. Rolfe. It also contains all the original illustrations made for the separate poems at a cost of upwards of $£ 5,000$, besides many others especially added for this work, nearly three hundred and fifty in all.

The popularity of Scott's poetry, the unique position of this elition for scholarship and accuracy, and the number, variely and excellence of the illustrations, combine to assure for this book inmediate popularity and a permanent standing.

I $2 \mathrm{mo}$, cloth, pp. xiii. and 306 , price 5 s.

\section{HEGEL'S PHILOSOPHY OF THE STATE AND OF HISTORY.}

AN Exposition.

By G. S. MORRIS.

Ph.D., of the University of Michigan.

This volume contains an expository resumé of two of Hegel's most poputar and important masterpieces. To the great number of those interested in the thoughtful discussion of questions relating to the foundations, the nature, the law of all social relations-domestic, civil, political and religious - the appearance of this work must be peculiarly timely and welcome.

\section{Preceding Volumes of the Series, 5s. each.}

Kant's Critique of PURE Reason. By Prof, G. S. MORRIs, Ph.D., of the University of Michigan.

Schelling's Transcendental Idealism. By Prof. John Watson, LL.D., of Queen's University.

Kant's Ethics. A Critical Exposition. By Ex-President Noah Porter, D.D., LL.D., of Yale College.

CHICAgo TIMES. - "This series offers an exceedingly valuable compendium of German philosophic thought, valuable in any tongue, and especially so in the English, in which there is nothing to compare with it." 
NEW A MERICAN WORKS.

8vo, cloth, price $6 s .6 d$.

\section{ENGLISH AND AMERICAN RAILROADS COMPARED.}

BY E. B. DORSEY, C.E.

With Discussion by W. W. Evans, T. C. Clakke, and E. P. North.

Royal 8vo, parchment, pp. I6, with a Map, price $2 s .6 d$.

\section{CHINA IN AMERICA:}

A Study in the Social Life of the Chinese in the Eastern Cities

of the United States.

BY STEW ART CULIN.

Read before the American Association for the Advancement of Science (Section of Anthropology), at the Thirty-ninth Meeting, New York, 1887.

Royal 8vo, cloth, pp. vii. and 134, with 23 plates, price 12s. 6 .

\section{EXPLORATIONS ON THE WEST COAST OF FLORIDA} AND IN THE OKEECHOBEE WILDERNESS.

With special reference to the Geology and Zoology of the Floridian Peninsula.

A Narrative of Researches undertaken under the auspices of the Wagner Free Institute of Science of Philadelphia.

BY ANGELO HEILPRIN.

$8 \mathrm{ro}$, cloth, price $\oint_{\mathrm{r}}$.

\section{AMERICAN METHODS OF COPPER SMELTING.}

\section{By Dr. E. D. PETERS.}

This is the best work on Copper Snctting in the langrzage, and no metallurgist, engineer, student or smelter can afford to be without it.

The work has been revised, enlarged, improved, and brought up to date since its appearance in the ENGINEERING AND MINING JOURNAL. The following are the opinions of some leading metallurgists upon this important work:- -

Dr. RICHTER, Professor of Metallurgy at Freiberg, Saxony, says :- "I am delighted to hear that the Articles on American Methods of Copper Smelting, which have appeared in the Engineering and Nining Journal, will shortly appear in book form. The enormous progress made in copper smelting in the United States will make this book of great value to the profession."

Mr. F. M. BARNES, Manager of Gustav Chaudoir and Co.'s Copper, Brass and Zinc Works, Simmering, near Vienna, Austria, says :- 'I consider Peters' book the best work published in any language since Percy's original work appeared."

Mr. H. M. HowE, the well-known metallurgist, says :- "Everyone engaged or interested in copper smelting should read Dr. Peters' work on that subject."

Mr. JAMEs E. MiLLs, of Quincy, Cal., says :- " This treatise presents in detail the late advances in practice, and gives a mass of inforination of a kind usually kept in unpublished notes of the metallurgist or left to the lore of craftsmen; just the kind that makes the least show of great learning, is the best evidence of practical knowledge and skill, and is eagerly sought by the metallurgist having work in hand." 


\section{REVIEWS AND MAGAZINES, \&C., NOW READY.}

\section{THE WESTMINSTER REVIEW.}

New Monthly Series.

Vol. II., No. 1. Fanuary, 1888. Price 2s. 6al.

Free Trade in Banking.

Dr. Johnson on Jreland.

Adulteration of Food and its Remedy.

Manxland.

Count Cavour.

Seven Weeks in Australia.

\author{
Mr. Gladstone's Rejoinder to Dr. Ingram. \\ Independent Section- \\ The Fishery Question: An American View of it. \\ Contemporary Literature. \\ Home Affairs.
}

Annual Subscription, including postage, 30 s.

\section{THE GEOLOGICAL MAGAZINE;}

\section{Or, Monthly Journal of Grology.}

Edited by Dr. H. Woodward. Fanutary, 1888. Price rs. $6 d$.

The Natural History of Lavas, illustrated by those of Krakatoa. By Prof. J. W. JUDD, F.R.S., Pres. Geol. Soc.

The Skull and Dermal Armour of Stegosaurus. By Prof. O. C. MARSH, Ph.D., LL.D., (Plates I., II. and III.) and Three Woodcuts.

Hertfordshire Subsidences. By A. C. C. Cameron. British Upper Tertiary Corals. By ALFRed BeLL.
On Organisms concerned in the Formation of Palzozoic Limestones. By Prof. H. A. Nicholson, M.D., D.Sc., F.G.S. (with Five Woodcuts).

Effects of Alternations of ' emperature on Terra-Cotta. By T. Mrtlakd Reade, C.E., F.G.S., F.R.I.B.A.

Notices of Memoirs-Reviews-Reports and Proceedings-Correspondence.

Annual Subscription, including postage, 18 s.

\section{THE B RITISH CHESS M A AZINE.}

Edited by JoHN WATKINSON.

No. 85. Famuary, 1888. Price $8 d$. Annual Sulscription, including postoge, 6 s.

\section{REVUE INTERNATIONALE.}

\section{Vol. XVI., No. 4. November 25, 1887.}

Riverita. Suite. Par A. PAlacio VAldes.

Le Paradoxe à travers les Siecles. Essai sur les Ex. centricités de l'Esprit Humain. Par F. Lolier.

Retour dans l'Inde Anglaise. Suite et Fin. Par A. DE GUBERNATIS.

A Propos de l'Affaire Caffarel. Par Abel Veuglaire.

Vol. XVI., No. 5 .

Le Principe de la Neutralisation Internationale Appliqué au Saint-Siège. Par E. JAclN1, ancien Ministre.

Riverita. Suite. Par A. Palacio Valdes.

Un Humoriste Anglais. Par Andrea Lo ForteRANDI.

La Question Monetaire en Angleterre. Par $H$. Chevassus.
La Constitution du Royaume de Roumanie. Suite et Fin. Par Louls Neulat.

Trois Livres Nouveaux. Par D. Melegari.

Chronique Politique. Par un Ancien Liplomate.

Chronique Financière-Bulletin des Livres. Annual Subscription, including postage, $36 s$.

\section{THE CALCUTTA REVIEW.}

\section{No. I7o, October, I887. Price 6s.}

'The Races and Lar.guages of Oceania. By R. CUST.

The National Assuciation for Supplying Female Medical Aid to the Women of India. By Mrs. M. A. Badley.

Hinul Civalization of the Brahamana Period. By

R. C. DutT, C S.

Christian Paganism. By H. G, KeEne.

Mihtary Officers in the Indian Police.
Some Old World Eastern Conq'ierers. By J.HuTToN. Campaigns aganst India. By Lielt.-Col. W. E. Guwan.

Comparative Penal Law.-II. By H. A. D. PHituss, C.S.

Jaw Reform and Chaos. By A. CASPERSz.

The Quarter.

Summary of Annual Report:-C Critical Notices. 


\section{Sourmal of the ganal asiatic Society. \\ ADVERTISEIMEITTS.}

\section{THE \\ INTERNATIONAL NUMISMATA ORIENTALIA.}

Edited by the late EDWARD THOMAS, C.I.E., F.R.S.

Roy. 4to. sd. pp. 84, with a Plate and a Map of the India of Manu. 9s. 6d.

ANCIENT INDIAN WEIGHTS. By E. THOMAS, F.R.S.

Roy. 4to. sd. pp. 44, with 6 Plates. $9 s$.

COINS OF THE URTUKI TURKUMANS.

By S'TANLEY LANE POOLE, C.C.C., OxFord.

Roy. 4to. sd. pp. viii. and 56, with Three Autotype Plates. 10s. 6d. THE COINAGE OF LYDIA AND PERSIA.

By BARCLAY V. HEAD, British Museum.

(A work which obtained the competitive Numismatic Prize in Paris, in 1879.)

Roy. 4to. sd. pp. iv. and 22, and 1 Plate. $5 s$.

THE COINS OF THE TULUNI DYNASTY.

BY EDWARD THOMAS ROGERS.

Roy. 4to. sd. pp. iv. and 65, with 8 Autotype Plates. $18 s$.

T H E P A R T H I A N C O I N A G E.

By PERCy Gardner, M.A., British Museum.

Roy. 4to. sd. pp. 60, with Plate. $10 s$.

ON THE ANCIENT COINS OF CEYLON.

BY T. W. RHYS DAVIDS, late of the Ceylon Civil Service.

The above 6 Parts complete Vol. I., Royal 4to. cloth, price $£ 313 s .6 d$.

VOL. II.

Paper wrapper, royal 4to. pp. xii. and 330, 279 Woodcuts, and a Plate of Alphabets, £2.

COINS OF THE JEWS.

Being a History of the Jewish Coinage and Money in the Old and New Testaments, BY F. W. MADDEN, M.R.A.S.

A New and enlarged Edition, brought-up to the latest discoveries.

VOL. III. PART I.

Royal 4to. pp. viii, and 48, with 5 Autotype lllustrations, price $8 s .6 d$.

The COINS of ARAKAN, of PEGU, and of BURMA. By Lieut.-General Sir ARTHUR PHAYRE, C.B., K.C.S.I., G.C.M.G., Lato Commissioner of British Burma.

Added to which is a Paper by EDWARD THOMAS, F.R.S., etc., On the Indian

Balhará and the Arabian Intercourse with India in the Ninth and following

Centuries.

Now ready. Vol. III., Part II. Royal 4to. pp. xii.-168, with 4 Plates and a Map. 25s

THE COINS OF SOUTHERN INDIA.

By $\operatorname{Sir}$ W. ELLIOT.

London: TRÜBNER \& CO.. 57 and 59, Ludgate Hill. 


\section{TRÜBNER'S ORIENTAL SERIES.}

All post 8vo., uniformly bound in cloth.

Linguistic and Oriental Essays. Second Series. By R. Cust. 218. Leaves from my Chinese Scrap-Book. By F. H. BaLforr. 78.6d. Manava-Dharma-Castra: the Code of Manu. Original Sanskrit Text with Critical Notes. By J. Jolly, Ph.D. 10s.6 $d$.

Masnavi i Ma'navi : the Spiritual Couplets of Maulana Jalalu-'d-din Muhammad-i-Rumí. 'Translated and Abridged by E. H. Whinfield, M.A. 7s. $6 a$.

Ancient Proverbs and Maxims from Burmese Sources; or the Niti Literature of Burma. By JaMES GraY. $6 s$.

Miscellaneous Papers relating to Indo-China. Reprinted from "Dalrymple's Oriental Repertory," the "Asiatick Researches," and the "Journal of the Asiatic Society of Bengal." Two vols. $21 s$.

The Satakas of Bhartrihari. Translated by the Rer. B. HaLE Wortham, B.A. $5 s$.

The Life and Works of Alexander Csoma de Körös, 1819-1842 By Theodone Duka, M.D. 98.

The Sankhya Aphorisms of Kapila. Translated by JAMes R. Baldantyne. Now entirely re-edited by Fitzedward Hall. $16 s$.

Manava-Dharma-Castra. The Ordinances of Manu. Translated by A. C. Burnelz. Completed and Edited by E. W. Hopkins. $12 s$.

Buddhist Records of the Western World. Translated by SaMder. BeAt. Two vols. $24 s$.

The Life of Buddha. Translated by W. Woopvilue Rocknill. 98. Tiele's Outlines of the History of Religion. Translated. $7 s .6 d$.

Religion in China. By J. Edkiss, D.D. 7s. 6d.

The Modern Languages of Africa. By R. Cust. Two vols. 258.

History of Burma. By Lieut.-General Sir A. P. Phayre. $14 s$.

Quatrains of Omar Khayyam. Text and Translation by E. H. WhINFIELD, M.A. 10s. 6d.

Udanavarga. By W. W. Rockнгіг. $9 s$.

The Philosophy of the Upanishads. By A. E. Govar, M.A. 9s.

History of the Egyptian Religion. By Dr. C. P. Trede. Translated by J. BalitNGaL. $7 s .6 d$.

The Indian Empire. By The Hon. Sir W. W. Hovmer, K.C.S.I., C.I.E., LL.D. New Edition. $21 s$.

Linguistic Essays. By Card Abed. $9 s$.

Tibetan Tales derived from Indian Sources. Translated by W. R. S. Ratston, M.A. $14 s$.

The Sarva-Darsana-Samgraha by Madava Acharya. Translated by E B. Cowell, M.A., and A. E. Govgh, M.A. 10s. $6 d$.

The Bhagavad Gita. Translated by J. Davies, M.A. 8s. $6 d$.

A Comprehensive Commentary to the Quran. By Rev. E. M. Wherry, M.A. In 4 Vols. Vols. I., II., and III. 12s. 6 d. each. Vol. IV. 10s. $6 \pi$. 
Tsuni- $\|$ Goam. The Supreme Being of the Khoi-Khoi. By T. HAHN. 7s. $6 d$.

Yusuf and Zulaikha. A Poem by JAMr. Translated by R. T. H. Ghifeith. 8s. $6 d$.

Faber's Mind of Mencius. Translated by Rev. A. B. Hutchinsor. 10s. $6 d$.

Quatrains of Omar Khayyam. Translated by E. H. Whrnfresd, M.A. "5s.

Eastern Proverbs and Emblems. By Rev. J. Lona. 6s.

The Mesnevi. Book I. Translated by J. W. ReDhouse. 218.

Indian Poetry. By E. Arvold, C.S.I. 7s. $6 d$.

Hindu Pantheism. By Major G. A. ЈАсов. $6 s$.

Hinda Philosophy. By J. Davies, M.A. $6 s$.

Religions of India. By A. Baritr. Translated. $16 s$.

Linguistic and Oriental Essays. By R. Cusr. $18 s$.

Classical Poetry of the Japanese. By B. H. Chamberlats. 7s. $6 d$. Buddhist Birth Stories; or, Jataka Tales. Translated by T. W. Rhys Davins. Vol. I. 18 s.

History of Esarhaddon. Translated by E. A. BudGe, B.A. 10s. 6d. The Gulistan; or, Rose Garden of Shekh Mushliu'd-din Sadi of Shiraz. Translated by E. B. EAstwick, F.R.S., etc. 10s. $6 d$.

Chinese Buddhism. By J. Edrins, D.D. $18 s$.

Selections from the Koran. By E. W. Lane. With Introduction by S. L. Poole. 9s.

Talmudic Miscellany. Compiled and Trans. by P. I. Hersion. 148.

Essays Relating to Indian subjects. By B. H. Hodgson. Two vols. $28 s$.

Gaudama, the Buddha of the Burmese. By the Right Rev. P. Bigandet, Bishop of Ramatha. Two vols. $21 s$.

Modern India and the Indians. By Monier Wrutrams, D.C.L. 148.

Metrical Translations from Sanskrit Writers. By J. MoIR, C.I.E. 148.

Classical Dictionary of Hindu Mythology, etc. By J. Dowson. 168.

The Birth of the War God, and other Poems. By KaLidasa. Translated by R. T. H. Griffith, M.A. 5 .

The Modern Languages of the East Indies. By R. Cost. $12 s$.

Weber's History of Indian Literature. Translated by J. MANN, M.A., and T. ZAChARtaE, Ph.D. Second Edition. 10s. $6 d$.

The Dhammapada. Translated from the Chinese by S. Beal. 7s. $6 d$.

Haug's Essays on. the Language, etc., of the Parsis. Edited by Dr. E. W. West. $16 s$.

LONDON: TRÜBNER \& CO,, 57 AND 59, IJUDGATE HILL. 


\section{PROPOSED ENGL ISH EDITION}

\section{OF THE

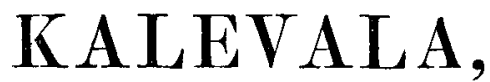

The Finnish Epic Poem upon which Longfellow modelled his "Sovg of Hiawatha."

Prospectus on application to W. F. KIRBY, 5, Burlington Gardens, Chiswick, London, W.

\section{TRÜBNER'S COLLECTION OF}

\section{Simplified Grammars of the Principal Asiatic and European Languages.}

Originally Edited by the late F. H. PALMER, M.A., and since his death by Dr. R. ROST, Librarian of the India Office Library.

All crown 8vo. uniformly bound in cloth.

HINDUSTANI, PERSIAN, AND ARABIC. By the late Professor E. H. PALMER. Second edition. pp. 112. 58.

HUNGARIAN. By I. Singer. pp. vi. and $88.4 s .6 d$. BASQUE. By W. vaN Ers. pp. xii. and 52. 3s. $6 d$. MALAGasy. By G. W. Parker. pp. 66. $5 s$. MODERN GREEK. By E. M. Geldart. pp. 68 . 2s. $6 d$. ROUMANIAN. By M. Torceanu. pp. viii. and 72. $5 s$. TIBETAN. By H. A. JäschкE. pp. viii. and 104. 5s. DANISH. By E. C. OTTÉ. pp. viii. and 66. 2s. $6 d$. TURKISH. By J. W. RedHouse. pp. xii. and 204. 10s. $6 d$. SWEDISH. By E. C. Orté. pp. xii. and 70. 2s. 6d. POLISH. By W. R. Morfill. pp. viii.-64. 3s. $6 d$. PALI. By Dr. Edward Müller. pp. xvi.-144. 7s. $6 d$. SANSKRIT. By HJälmar Edgren. pp. $190.10 s .6 d$. JAPANESE. By B. H. Chamberlain. pp. 114.58. ALBANIAN (Grammaire Albanaise). ByP.W. pp. 178. 7s.6d. SERBIAN. By W. R. Morfill. pp. viii. and 72. 4s. $6 d$.

The following are in preparation:-

Assyrian, by Prof. Sayce.

Bengali, by J. F. Blumhardt, of the British Museum.

Burmese, by Dr. E. Forchammer.

Cymric and Gaelic, by H. Jenner, of the British Museum.

Finnic, by Prof. Otto Donner, Helsingfors. Hebrew, by Dr. Ginsburg.

Icelandic, by Dr. Wimmer, Copenhagen.
Lettish, by Dr. M. I. A. Völkel.

Lithuanian, by Dr. M. I. A. Völkel.

Malay, by W. E. Maxwell, of the Inner Temple, Barrister-at-Law.

Portuguese, by Walter de Gray Birch. Russian, Bohemian and Bulgarian, by W. R. Morfill, of Oxford.

Sinhalese, by Dr. Edward Müller.

Panjabi, by W. St. Clair Tisdall.

LONDON : TRÜBNER \& CO. 


\section{Ropal asiatic bociety of Great ZBritain and Ireland.}

22, ALBEMARLE STREET, LONDON.

For the Investigation and Encouragement of Arts, Sciences, and Literature in relation to Asia.

PRESIDENT.

Sir THOMAS F. WADE, K.C.B.

DIRECTOR.

Major-Gen. Sir H. C. RAWLINSON, K.C.B., D.C.L., LL.D., F.R.S.

\section{VICE-PRESIDENTS.}

Sir T. EDWARD COLEBROOKE, Bart.

Major-Gen. Sir A. CUNNINGHAM, R.E., K.C.I.E., C.S.I.

The Rev. Professor A. H. SAYCE, M.A.

Coloner HENRY YULE, R.E., C.B., LL.D.

\section{COUNCIL.}

Professor CECIL BENDALL, M.A.

F. V. DICKINS, EsQ.

Professor R. K. DOUglas.

THEODORE DUKA, EsQ., M.D.

CoLONEL GEORGE E. FRYER.

MAJOR-GEN. SIR FREDERIC J. GOLDSMID, C.B., K.C.S.I.

H. H. HOWORTH, EsQ., F.S.A., M.P.

HENRY C. KAY, EsQ.

Professor TERRIEN DE LACOUPERIE, Ph. \& Litt.D.

GENERAL ROBERT MACLAGAN, R.E., F.R.S.E.

Professor Sir MONIER MONIER-WILliaMs, K.C.I.E., M.A., D.C.I. HENRY MORRIS, EsQ.

Professor W. ROBERTSON SMITH, M.A.

T. H. THORNTON, Esq., C.S.I., D.C.L.

M. J. WALHOUSE, EsQ.

\section{TREASURER.}

E. L. BRANDRETH, Esa.

\section{SECRETARY.}

Professor T. W. RHYS DAVIDS.

HON. SECRETARY.

ROBERT N. CUST, EsQ., LL.D.

The Society consists of (1) Resident Members (whose place of abode is in Great Britain or Ireland), Annual Subscription, $\$ 33 s$.; (2) Non-Resident Members (not living in Great Britain or Ireland), Annual Subscription, £1 1s.; and (3) Honorary Members, persons of distinction, British or Foreign, nominated by the Council.

All Members, Resident, Non-Resident, and Honorary, are entitled to receive the Society's Journal, published quarterly, containing original papers by, or communicated through, Members of the Society. They are also entitled to attend the meetings (held usually once a month from November to June inclusive, at 4 p.m.); to take part in the discussion of the papers; to vote for new Members; and to have the use of the Society's Library.

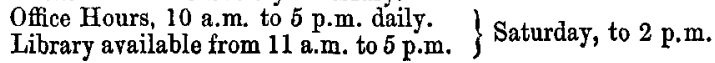




\section{ROYAL ASIATIC SOCIETY'S JOURNAL.}

The following is a List of the Articles, etc., published last Quarter in PART IV., VOL. XIX.

Art. XVI.-The Miryeks or Stone-men of Corea. By Prof. Terrien DE LaCOUPERIE, Ph. \& Litt.D., M.R.A.S. (With a Plate).

Art. XVII.-The Pre-Sanskrit Element in Ancient Tamil Litera-

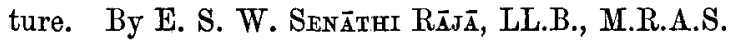

Arr. XVIII.-Were Zenobia and Zebbā'u Identical? By J. W. ReDHouse, M.R.A.S., C.M.G., Litt.D., etc.

Art. XIX.-The First Mandala of the Rig-Veda. By Frederic Prncott, M.R.A.S.

Arr. XX.-Origin and Development of the Cuneiform Syllabary. By G. Bertin, M.R.A.S.

Art. XXI.-The Babylonian Chronicle. By Theo. G. Pinches, M.R.A.S.

Notes of the Quarter

1. Reports of Meetings of the Royal Asiatic Society, Session 1886-7.

2. Proceedings of Asiatic or Oriental Societies.

3. Correspondence-(1) The Persian for Rouble, by Capt. T. G. de Guiraudon. (2) The Bibliography of Africa, by Capt. T. G. de Guiraudon.

4. Obituary Notices.

5. Excerpta Orientalia.

6. Notes contributed by the Hon. Secretary.

7. Special Committee, Royal Asiatic Society.

INDEX. 


\section{CONTENTS OF VOL. XX. PART I.}

[NEW SERIBR.]

ORIGINAL COMMUNICATIONS.

ART. I.-The Cuneiform Inscriptions of Van. By the Rev. Professor A. H. SAYCE, M.A., M.R.A.S...... 1

Arr. II.-Some Suggestions of Origin in Indian Architecture. By William Simpson, M.R.A.S. ......... 49

Art. IIL.-The Chaghatāi Mughals. By E. E. Ocrver, M.I.C.E., M.R.A.S. .................

Art. IV.-Sachau's Albirúní. By Major-General Sir F. J. GoLdsMid, C.B., K.C.S.I., M.R.A.S.

\section{Correspondence}

1. The Bibliography of Africa, by Capt. T. G. de Guiraudon ........................ 143

2. Notes on African Philology, by Capt. T. G. de Guiraudon ........................ 144

3. The Migration of Buddhist Stories, by Serge d'Oldenburg .................... 147

4. Kālidāsa in Ceylon, 522, by T. W. Rhys Davids.. 148

NOTES OF THE QUARTER

1. Reports of Meetings of the Royal Asiatic Society, Session $1887-8 \ldots \ldots \ldots \ldots \ldots \ldots \ldots \ldots \ldots, 150$

2. Proceedings of Asiatic or Oriental Societies ...... 153

3. Contents of Foreign Oriental Journals ........ 154

4. Contributions to the Notes of the Quarter by the Hon. Secretary .................. 156

5. Excerpta Orientalia................... 157 